\title{
PEMANFAATAN TEKHNOLOGI DALAM UPAYA MENINGKATKAN PRODUKTIVITAS USAHA KECIL
}

\author{
Oleh: \\ Intan Shaferi 1) \\ Alisa Tri Nawarini ${ }^{2)}$ \\ Meutia Karunia Dewi ${ }^{3)}$ \\ Email ${ }^{1}$ : ishaferi@yahoo.com \\ 1) 2) ${ }^{3)}$ Dosen Fakultas Ekonomi \& Bisnis, Universitas Jenderal Soedirman
}

\begin{abstract}
Small medium enterprises seems to have change for a better production with their quality and quantity. Still we have SMEs that using traditional method to produce their product. That means unoptimal production because of limitation of time and some unexpected failure that may happened during production. So that, by using touch of technology, will minimizing the failure, effectiving time, and incrasing units of production.
\end{abstract}

Keywords : SMEs, traditional method, techonology, productivity.

\section{PENDAHULUAN}

\section{Latar Belakang}

Usaha Kecil dan Menengah (UKM) merupakan sektor mikro dalam perekonomian Indonesia yang memiliki prospektif yang baik. Dengan keberadaan UKM ini, penyerapan tenaga kerja menjadi dapat dioptimalkan melalui upaya pemberdayaan mandiri dalam berbagai sektor ekonomi. Salah satu sektor UKM yang memiliki potensi besar adalah sektor UKM dalam bidang pembuatan makanan ringan dalam kemasan.

UKM pada bidang produksi makanan ringan telah berkembang dengan sangat pesat saat ini. Wilayah Kabupaten Banyumas salah satu dari begitu banyaknya wilayah di Indonesia, dimana potensi kuliner saat ini sedang berkembang dengan sangat prospektif. Dengan kekayaan sumber daya produksi yang dimiliki, UKM dalam bidang pembuatan makanan ringan ini dapat menjadi faktor esensial yang memperkaya potensi lokal daerah jika dapat dimanfaatkan dengan optimal.

Salah satu kendala utama yang dihadapi UKM, terutama dalam aspek produksi adalah masih terbatasnya pengetahuan pelaku UKM terhadap pemanfaatan tekhnologi tepat guna dalam upaya meningkatkan produktivitas usahanya. Kendala tersebut diakibatkan oleh banyak faktor, seperti misalnya karena masih rendahnya tingkat pemahaman dan tingkat aksesibilitas terhadap perkembangan tekhnologi.

Dengan adanya kendala tersebut, potensi produk makanan ringan yang dihasilkan oleh pelaku UKM menjadi tidak optimal. Kendala dalam bidang tekhnologi produksi telah mengakibatkan pelaku UKM banyak mengabaikan potensi pasar yang mungkin diraih. Adanya pemberian pengetahuan dan bantuan terkait dengan tekhnologi 
produksi bagi pelaku UKM diharapkan akan dapat meningkatkan produktivtas usaha UKM makanan ringan sehingga potensi pasar yang ada juga dapat dioptimalkan.

Usaha pembuatan makanan, yang merupakan mitra dalam program pengabdian kepada masyarakat ini, yaitu usaha makanan ringan "Sellina" merupakan salah satu UMKM yang memilki potensi besar untuk dikembangkan. Usaha ini berlokasi di Purwokerto Utara. Meskipun masih berskala kecil, tetapi pemilik usaha ini telah menerapkan sistem pengendalian kualitas yang cukup baik. Namun demikian masih menggunakan cara manual dalam pembuatan produknya. Cakupan pemasaran produk "Sellina" yang luas mengakibatkan munculnya kebutuhan penambahan alat produksi agar dapat melayani pasar secara optimal.

\section{Rumusan Masalah}

Berdasarkan penjelasan latar belakang di atas, perumusan masalah yang dajukan adalah sebagai berikut:

Proses produksi usaha pembuatan makanan ringan "Sellina" masih menggunakan tekhnologi manual yang sangat sederhana. Oleh karena itu skala produksi yang dihasilkanpun juga masih belum optimal. Dengan adanya pemanfaatan tekhnologi produksi yang modern, produktivitas usaha pembuatan makanan ringan "Sellina" diharapkan dapat ditingkatkan.

Potensi pasar yang dimiliki produk "Sellina" cukup besar dan prospektif. Dengan pemanfaatan tekhnologi produksi tepat guna diharapkan tingkat skala produksi yang dihasilkan dapat ditingkatkan sehingga prospek usaha makanan ringan "Sellina" untuk berkembang lebih besar menjadi terbuka lebar.

\section{KAJIAN PUSTAKA \\ 1. Teknologi}

Proses teknologi adalah perwujudan dari empat elemen dan interaksi antara keempatnya yaitu: technoware (Perangkat teknis, peralatan produksi, fasilitas fisik mencakup peralatan, perlengkapan, dll), humanware (merupakan kemampuan SDM yang meliputi pengetahuan, ketrampilan/keahlian, kebijakan, kreativitas, prestasi dan pengalaman seseorang/sekelompok orang dalam memenfaatkan SDA dan teknologi), infoware (merupakan perangkat informasi yang berkaitan dengan proses, prosedur, teknik, metode, dll), dan orgaware (merupakan perangkat organisasi dan dan peraturan di dalamnya utnuk mewadahi perangkat teknis, SDM, dan informasi) (Smith \& Sharif,2007).

Dalam proposal ini, teknologi lebih menekankan pada elemen yang pertama yaitu technoware. Meskipun demikian, secara jangka panjang kombinasi dari keempat elemen tersebutlah yang akan mendorong daya saing dari suatu bisnis. Selain itu, teknologi menjadi komponen penting dalam menjalankan bisnis karena merupakan salah satu sumber kekuatan bagi produktivitas dan menyokong pertumbuhan kinerja (Clark \& Abernathy dalam Ellitan 2003).

\section{Produktivitas}

Produktivitas adalah merupakan hasil bagi antara output dengan keseluruhan atau salah satu faktor dengan keseluruhan atau salah satu faktor produksi yang digunakan, antara lain modal, investasi yang dikeluarkan dan 
bahan baku yang digunakan (The Organization for European Economic Cooperation [OEEC], 1950; dalam Desheng, 2007). Sedangkan, Sinungan (2005) dalam Astuti, dkk (2013) mendefinisikan produktivitas sebagai perbandingan ukuran harga bagi masukan dan hasil, juga merupakan perbedaan antara kumpulan jumlah pengeluaran dan masukkan yang dinyatakan dalam satuan - satuan (unit) umum.

Pengukuran kerja dapat dilihat pada produktivitas yang dihasilkan. Pada konsepnya, produktivitas menunjukkan adanya kaitan antara hasil kerja dengan satuan waktu yang dibutuhkan untuk menghasilkan suatu produk dari seorang tenaga kerja (Sitohang, 1997). Dengan kata lain dapat dinyatakan bahwa seorang tenaga kerja menunjukkan tingkat produktivitas yang lebih tinggi bila ia mampu menghasilkan produk yang sesuai dengan standart yang diterapkan dalam satuan waktu yang telah ditetapkan (Sitohang, 1997). Oleh karena itu, dalam bekerja, kecepatan dan ketetpatan dibutuhkan agar dapat efektif dan efisien

Produktivitas dan teknologi merupakan entitas yang berbeda, tetapi saling berhubungan, terutama dalam pemanfaatan teknologi informasi sehingga investasi untuk penerapan teknologi baru dalam suatu perusahaan akan mempengaruhi peningkatan produktivitas (Fernandez, 2008). Produktivitas biasanya diukur berdasarkan rasio output dengan indikator input yang berbantuk profit, modal, energy dan bahan baku (Astuti, dkk; 2013).

\section{METODE PELAKSANAAN KEGIATAN}

\section{Pemecahan Masalah}

Berdasarkan rumusan masalah yang ada, terdapat beberapa alternatif cara dalam mencapai tujuan.

1. Memberikan pengetahuan mengenai pemanfaatan teknologi yang dapat membantu produktivitas usaha makanan"Sellina".

2. Pemanfaatan teknologi akan memudahkan dan mempercepat waktu kerja sehingga akan mampu meingkatkan produktivitas. Dengan pemanfaatan teknologi kapasitas produksi dapat ditingkatkan, dan secara kualitas juga akan lebih baik karena dengan adanya alat bantu dalam produksi maka makanan yang dihasilkan kualitas satu makanan dengan lainnya akan sama. Hal ini berbeda jika pengerjaan produksi makanan dilakukan dengan tangan saja, maka hasil dari campuran bahan masih belum rata dan tercampur secara maskimal. Tentu saja dalam hal ini akan menimbulkan efek baik dalam kualitas makanan tersebut dari sisi tekstur dan rasa.

\section{Khalayak Sasaran}

Khalayak sasaran pengabdian yaitu pemilik dan pengelola usaha makanan"Sellina" yang berlokasi di Desa Karangpucung Kecamatan Purwokerto Selatan dengan produk makanan ringan atau snack berupa stick dan kue.

\section{Metode Pemecahan Masalah}

Cara penyelesaian masalah yang dihadapi telah terangkai dalam pemecahan masalah pada poin sebelumnya. Rincian kegiatan mencakup metode pemecahan masalah tersaji sebagai berikut. 
1. Pengenalan teknologi berupa alatalat dalam pembuatan adonan makanan seperti mixer, alat-alat pencampur adonan, oven, alat perekat kemasan serta bahan-bahan untuk keperluan pembuatan kue kepada mitra usaha makanan "Sellina" dengan memberikan pengetahuan arti pemanfaatan teknologi tersebut dalam proses produksi.

2. Pelatihan penggunaan alat-alat produksi makanan. Penggunaan alatberupa mixer, alat-alat pencampur adonan, oven, dan alat perekat kemasan serta bahan-bahan untuk keperluan pembuatan kue. Hal tersebut diharapkan akan dapat meningkatkan produktivitas mitra karena akan mempercepat proses produksi.

\section{DISKUSI \& ANALISIS \\ 1. Kegiatan yang Dilakukan}

Dalam pelaksanaan kegiatan ini, pelaksana melaksanakan tiga kegiatan utama sebagai berikut:

1. Kegiatan observasi mendalam terhadap kebutuhan mitra sebagai cara untuk menggali informasi mengenai kesulitan yang dihadapi dan bagaimana tim dapat membantu mitra memecahkan masalah efektifitas produksi. Ternyata kebutuhan mitra yaitu alat bantu dalam produksi dan penjualan yang selama ini belum dimiliki dan atau masih menggunakan manual seperti lilin untuk mengikat plastik kemasan.

2. Kegiatan pemberian bantuan alat sebagai kebutuhan mitra yang digunakan sebagai pemecahan masalah efektifitas produksi, karena sebelumnya mitra menggunakan alat manual dalam pekerjaan sehari-hari yang menyita banyak waktu dan tenaga. Alat yang diberikan yaitu mixer agar dapat membuat adonan dengan maksimal dan juga oven untuk membuat beberapa kue yang sebelumnya mengikut kepada orang lain. Alat lain yaitu perekat kemasan atau selaer yang digunakan dalam mengikat palstik kemasan supaya kerenyahan makanan dapat terjaga.

3. Kegiatan pendampingan dan evaluasi. Setelah mitra mendapatkan alat dan menggunakan, maka tim mendampingi dengan cara intensif dalam komunikasi tentang kelemahan dan kelebihan alat-alat yang digunakan mitra serta mengevaluasi hasil yang diproduksi, apakah benar dalam efektifitas kegiatan produksi dan hasilnya dapat bermanfaat bagi mitra.

\section{Evaluasi Terhadap Kegiatan yang Telah Dilakukan}

Program yang telah dilakukan mendapat respon positif dari mitra. Program dapat diterima dan berjalan dengan baik. Tidak terdapat kendala berarti dalam melaksanakan program karena langkah yang dilakukan sesuai yang telah dirancanakan dari proses survey lokasi, identifikasi masalah, dan penyusunan penyelesaian masalah. Sehingga dalam hal ini mitra dan tim pelaksana program pengabdian telah sepakat dengan program ini.

Tema program ini adalah mengangkat pemanfaatan tekhnologi pada usaha rumahan terurama dalam hal produksi dan packaging. Bantuan yang diberikan sesuai dengan tema berkisar penggunaan alat bantu guna mempermudah dalam proses produksi hingga pengemasan. Alat bantu produksi yang diberikan yaitu mixer Phillips dengan 
bowl untuk memudahkan dalam mencampurkan bahan dan meratakan adonan sehingga tidak perlu menggunakan tangan secara manual yang cukup memakan waktu dan tenaga. Bantuan lain yaitu oven. Oven ini digunakan untuk produksi makanan yang sebelumnya tidak dapat dilakukan di rumah sendiri. Semua mitra harus menumpang di tempat orang lain jika akan melakukan produksi kue. Obarang lain yaitu alat press atau sealer. Impuls sealer ini digunakan untuk packaging sehingga kemasan akan kedap udara dan memperpanjang kerennyahan makanan. Sebelumnya mitra menggunakan lilin dalam melakukan proses ini. Alat lainyaitu untuk varian makanan seperti loyang dan perlengkapan penunjang seperti kain dan sebagainya. Hana-bahan seperti terigu, mentega, vanili dan kebutuhan lain untuk membantu produksi, serta isisan snack kering yang digunakan untuk usaha dagangnya.

Sejauh ini hingga program ditutup, semua berlanjan lancar. Kekurangan dalam program yaitu ada alat yang semua dirancanakan dengan listrik, yaitu oven, karena demi kelangsungan ke depan pembebanan listrik maka mitra lebih memilih menggunakan oven dengan kompor. Selebihnya segala aktivitas dapat dijalankan sesuai rencana.

\section{KESIMPULAN DAN SARAN}

\section{Kesimpulan}

Kesimpulan yang dapat diambil dari pelaksanaan kegiatan pengabdian kepada masyarakat yang telah dilaksanakan adalah sebagai berikut:

1. Teknologi sangat diperlukan dalam proses produksi sehingga lebih efisien dalam hal waktu dan tenaga.
2. Penggunaan alat bantu yang diberikan kepada mitra dapat menunjang proses produksi dan memberikan motivasi baru dalam memproduksi makanan.

\section{VI.2 Saran}

Mitra dapat menambah kapasitas produksi dengan adanya alat yang telah diberikan sehingga efektifitas produksi bukan hanya sebatas penghematan tanga dan waktu tapi juga meningkatkan keuntungan dari hasil produksi dan penjualan yang dapat ditingkatkan karena telah adanya penghematan waktu dan tenaga.

\section{DAFTAR PUSTAKA}

Astuti, Mudji; dkk . 2013. Peningkatan Produktivitas Usaha Kecil \& Menengah (Ukm) Berbasis Technology Content untuk Mendukung Pelaksanaan Masterplan Percepatan Dan Perluasan Pembangunan Ekonomi Indonesia (Mp3ei) 2011-2025. Prosiding Call for Paper 2013. Fakultas Ekonomi Universitas Muhammadiyah Sidoarjo.

Desheng Dash Wu, Chien Ta Bruce Ho. 2007. Productivity and efficiency analysis of Taiwan integrated circuit industry. International journal of productivity and performance management, vol 56 no 8, pp 715-730.

Ellitan. 2003. Peran Sumber Daya DalamMeningkatkan Pengaruh Teknologi Terhadap Produktivitas. Jurnal Manajemen \& Kewirausahaan, Vol 5 No 2, September, 155-170. 


\section{http://jp.feb.unsoed.ac.id}

Fernandez. 2008. Firm Productivity In Bangladesh Manufacturing Industries. World Development, Vol 36 No 10 pp 1725-1744.

Sitohang, Hotma. 1997. Pengaruh Teknologi dan Lingkungan Kerja pada Produktivitas Sumber Daya Manusia pada Sektor
Konstruksi. Tesis Perpustakaan UI.

Smith, Sharif . 2007. Understanding And Acquiring Technology Assets For Global Competition. Technovation 27, pp 643-649. 